and the sum obtained by this method is $f(x)$ :

where

$$
f(x)=\int_{0}^{\infty} e^{-x t} F(t) d t,
$$

$$
F(t)=A_{0}+\frac{A_{1}}{1 !} x+\frac{A_{2}}{2 !} x^{2}+\cdots .
$$

A number $l$ exists such that this integral converges when $R(x)>l$ and diverges when $R(x)<l$. This number $l$ plays a fundamental rôle as regards the properties of the function $f(x)$ defined by the factorial series.

We have here in a special case two aspects of the general theory of summability of the series $\Omega(x)$, a theory of importance the development of which will lead to significant extensions of our knowledge of one of the most fundamental expansion problems in analysis. Early in 1917, Mr. Charles F. Green, a student at the University of Illinois, was beginning work upon this subject, looking towards a doctor's dissertation; but his labor has been interrupted by more pressing duties and he is now engaged as a pilot in the aviation service with the American Army in France.

UNIVERSITY OF IlLINOIS.

\title{
ON THE PROBLEM OF THE RESISTANCE INTEGRAL.
}

BY PROFESSOR TSURUICHI HAYASHI.

THE problem of minimizing the resistance integral seems to be of three main varieties.

1. Newton's problem:*

To get a solid of revolution formed by revolving a curve passing through two given points about an axis which shall experience a minimum resistance when it moves through a fluid in the direction of its axis.

The solution is the well-known transcendental curve.

* Philosophiæ Naturalis Principia Mathematica, 1687, Book 2, Section 7, Prop. 34, Scholium. 
2. Tarleton's problem:*

To get a solid of revolution on a given base with a given volume which shall experience a minimum resistance when it moves through a fluid in the direction of its axis.

The solution is a hypocycloid of three cusps. $\dagger$

3. Euler's problem: $\ddagger$

The full enunciation of this problem is found in Professor G. H. Light's paper in the July number of this Bulletin, 1918 , volume 24 , page 480 . The solution can be easily obtained in its parametrical form, which is quite the same as that for Tarleton's problem. So without using Professor Light's method, we may use Todhunter's method to show that the solution is a hypocycloid of three cusps. Todhunter's method depends on the relation

$$
d y / d x=p=\tan \phi,
$$

and seems to be more easy and more natural.

August, 1918.

\section{NOTE ON EDITIONS OF VON STAUDT'S GEOMETRIE DER LAGE.}

BY PROFESSOR R. C. ARCHIBALD

(1) The first editions of K. G. C. von Staudt's Geometrie der Lage (G.) and Beiträge zur Geometrie der Lage (B.) were issued in 4 parts, paper covers, by "Verlag von Bauer und Raspe (Julius Merz)," Nürnberg, 1847-1860,§ each of the four parts having a separate title page.

(2) An Italian translation of (G.), and of some paragraphs of (B.), was published in 1889.\|

* Philosophical Magazine, 4th series, vol. 34 (1867).

† See Todhunter's Researches in the Calculus of Variations, 1871, pp. 196-198. It is reproduced in Carll's Calculus of Variations, 1881, pp. 144146.

$\ddagger$ Scientia Navalis, Prop. 53.

$\S(\mathrm{G}$.): 1847 (on the reverse of the title page is: "Erlangen, gedruckt bei J. J. Barfus," pp. $6+216$ ). (B.): 1856 ("Druck von Junge \& Sohn in Erlangen,": pp. 6 + 130), 1857 ("Druck von Junge \& Sohn in Erlangen," pp. 131-284), 1860 ("Druck der A. E. Junge'schen Universitätsbuchdruckerei," pp. $6+285-396)$.

| Geometria di Posizione di Giorgio Carlo Cristiano v. Staudt. Traduzione dal tedesco a cura del dott. M. Pieri, professore all'Accademia militare, preceduta da una studio del Prof. C. Segre sulla vita e le opere del v. Staudt. Torino, Bocca, $28+233$ pp. 